\title{
Nova Imago Urbis: the transformation of city walls in early Renaissance as a model to recover the image of contemporary city
}

\author{
Aritz Díez Oronoz \\ Departamento de Arquitectura. Escuela Técnica Superior de Arquitectura, Donostia-San \\ Sebastian. Spain \\ E-mail: aritz.diez@ehu.eus
}

\begin{abstract}
The transformation of fortifications in early Renaissance supposed a revolution not only from a strictly military view: at the same time the medieval fortifications were replaced by others designed to deal with the artillery, the urban walls which was part of the essence of the European cities from Antiquity had to be transformed. Aware of this problem, several generations of architects coinciding with those that promoted the Renaissance in Italy during the quattrocento and cinquecento, tried to look for a functional, formal and symbolic resolution to this incipient fortifications against the artillery. The challenge was to give a new form to the new defence works, a "form" that at the same time allowed the maximum of technological correspondence and the maximum of symbolic and visual significance for the city. This article discusses the consequences this process had for the definition of the city's image from Renaissance to 19th century and exposes some recent project examples that, following the lessons learned during this process of redefinition of fortifications, tries to give back to the current historic cities its lost image.
\end{abstract}

Keywords: Fortifications, Image of the City, Imago Urbis, Renaissance

\section{Introduction}

The development of our European cities has drastically transformed its structure and positioning in relation to its territory. From an organization in which both -the City and its territory- responded to essentially distinct entities, the city has extend its influence to its surrounding, even occupying its environment completely. This kind of development has made disappear in a short period of time, those typical tools which cities used to exhibit themselves as single entities stood out from their natural surroundings - remembering these words of Goethe on his journey through Italy as belle natura fata per il huomo, differentiated from nature itself.
This city concept as a microcosm - as a self-space singularized by and for the human - gave rise from the spring of the first urban organizations to the establishment of some city-constituent concepts, largely invariant and traceable throughout all urban acts to date; concepts which are closely related to our need to position ourselves in the world and organise, both physically and symbolically, our surrounding landscape.

These mental connections derived from this primitive act of inhabiting - essence of the City after all - have lay down from the origin of our western civilizations the norms for an inhabiting style that in essence remained invariant, producing some types of cities that - although diverse in immediate signs - responded to the same way of asserting themselves against 
nature. Such is the continuity and the trace left by this attitude that it even reborns in an author distant with this idea of the western city as Le Corbusier:

Primitive man has brought his chariot to a stop, he decides that here shall be his native soil. He chooses a glade, he cuts down the trees which are too close, he levels the earth around; he opens up the road which will carry him to the river or to those of his tribe whom he has just left; he drives in the stakes which are to steady his tent. He surrounds this tent with a palisade in which he arranges a doorway. The road is as straight as he can manage it with his implements, his arms and his time. The pegs of his tent describe a square, a hexagon or an octagon. The palisade forms a rectangle whose four angles are equal. The door of his hut is on the axis of the enclosure - and the door of the enclosure faces exactly the door of the hut.

This primitive man called up in this fragment of the famous Vers une Architecture becomes aware of his position and makes it his own through two simple but transcendental acts: the delimitation of an enclosure - he surrounds this tent with a palisade in which he arranges a doorway - and the creation of an inner geometric order - the pegs of his tent describe a square, a hexagon or an octagon; the palisade forms a rectangle whose four angles are equal - which differs from the outer natural order. Therefore, reappear in this text those two invariants which - as Paolo Sica also states - are coincident with those who have long dominated not only the form, but also the City idea: the concept of limit and the concept of center.

Idea of limit and idea of center, outer boundary and inner trace which, as a speedy response of humans against the virgin nature, are already represented from the earliest civilizations. As example, this notion appears in the Egyptian hieroglyphic sign of City an inner cross enclosed by a circle - or in the primitive idea of labyrinth, proving not only the material transposition of these two concepts to the form of the city, but also its strong symbolic change that survived even to our days. In this sense, the debt of the pictogram Le Poème de l'Angle Droit made by the hand of Le Corbusier to these two previous symbols is evident. [figure 1].

Of this pairing, I am interested in arguing the importance of this idea of limit for the establishment of the City itself. I will do it paying attention to one of the most critical moments in the evolution of this urban boundary: the transformation of the medieval walled enclosures of the European cities in fortifications prepared to face the new artillery, and the consequent change caused in the city image, symbolized until then through the
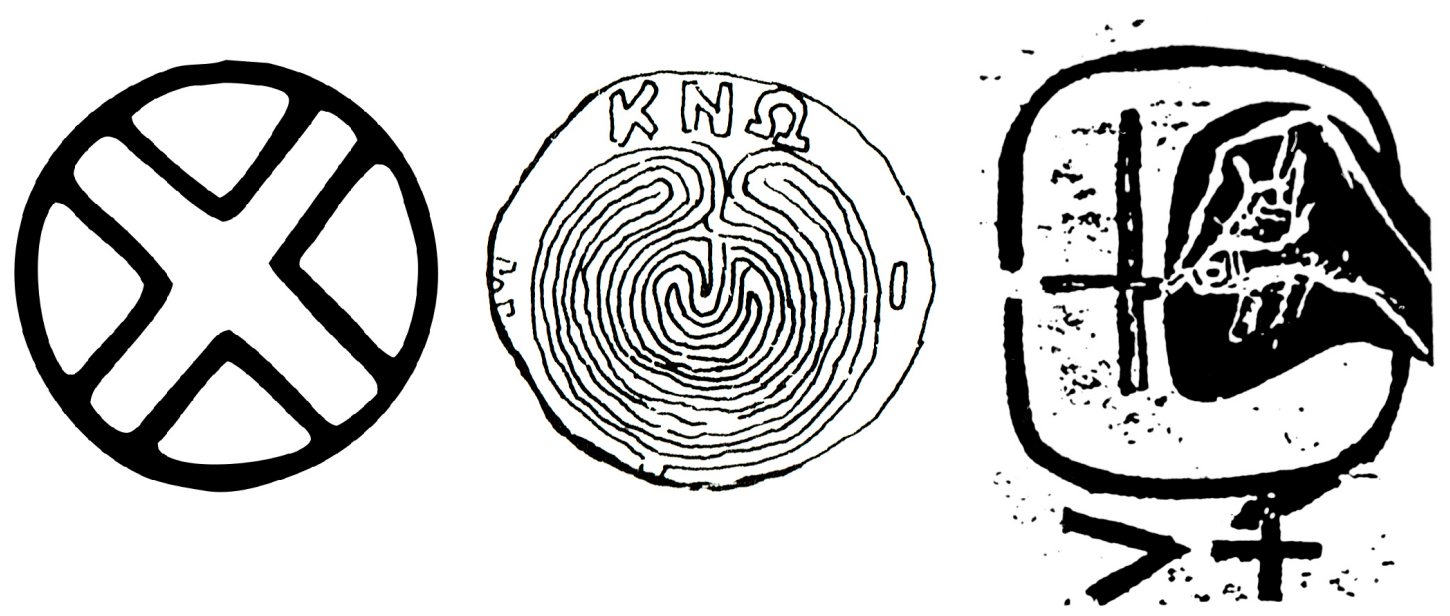

Figure 1. Hieroglyph of city, Minoan coin representing a labyrinth and drawing for Le Poème de L'Angle Droit of Le Corbusier 
defined image of medieval crenelated walls and elevated towers. Considering that albertian parallel of thinking the city as a large house, the city perimeter itself -its precinct- shapes not only its simple urban enclosure, but also sets up the true façade of the city, an essential part of it structure which is crucial to its representation outward

\section{Consequences of the transformation of medieval fortifications for the European cities image}

The significance of this urban façade for the city's own image is clear if we consider not only its functional use, but also the symbolic and formal meaning of the enclosure par excellence of this urban limit idea: the city walls.

Besides fulfilling a clearly functional role, that of defense, these walls inevitably assumed for themselves those values that their own nature as an essential part of this urban pairing - the limit and the center - demand them. A glance to the symbology related to the fortifications is enough to understand the close link between the walls and those symbolicrepresentative connotations of the urban boundary: from the mythological meaning of walls in the Greek archaic culture to the founding rituals of the Roman pomerium, from Biblical significance of the fall of Jericho's walls to the vital importance that them took in the medieval representations of the City, the formal definition of this urban boundary was essential to define the way in which the city itself was shown outwards. It is such the connection between both them in some periods - between the city and its walls - that to give an example, Isidore of Seville could even claim that the city itself was its own walls, as we can still suspect in the Renaissance fresco made by Benozzo Gozzoli at Montefalco, which represents the city of Arezzo. [figure 2]

In spite of the changes produced over the centuries and transformations caused by the different conditions of epochs, it can be affirmed however, that both antique fortifications Greek and Roman ones - and even other as distanced in time from them as medieval ones,

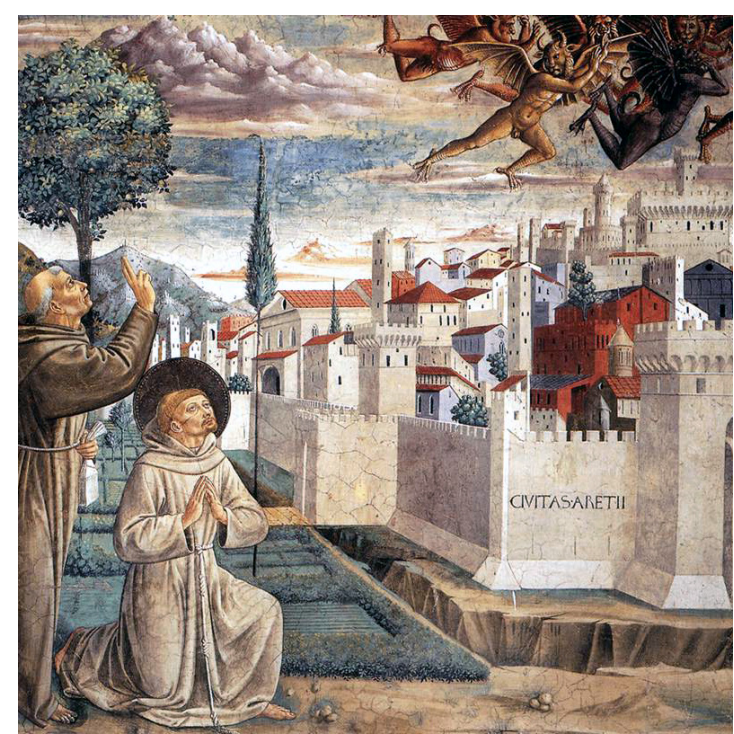

Figure 2. San Francisco expels demons from Arezzo, Benozzo Gozzoli

were in accordance with one same structure. Therefore, this functional correspondence preserved a certain formal continuity that connects not only these medieval fortifications to its predecessors, but also links the medieval urban image with those cities of Antiquity.

However, this affinity of the spirits in relation to forms - reusing this quote of Henri Focillon - was truncated during the 15th century due to the appearance of the cannon as a siege weapon. The changes forced by the new siege techniques transformed radically the functional base that underpinned the unique ensemble of symbols and formal repertoires of medieval fortifications. Beyond the functional challenges that this supposed - there is a large bibliography about it - the replacement of the ancient medieval walls imply the research of a new formal repertoire for this city boundary - is walls - that could replace this formal complex system not only functionally, but also from its representative and symbolic sphere.

Fully aware of this necessity, several generations of architects - those who coincide with the generations who promoted the Renaissance in Italy during the quattrocento and finally settled it in early cinquecento tried to find a functional, formal and symbolic resolution to the budding fortifications against artillery. From Francesco di Giorgio Martini to Baldassarre Peruzzi, from Leonardo to Michelangelo and, with more intense if it fits, 
all the generations of the Sangallo family from Giuliano to Antonio the young, worked to promote this transformations, completely aware of its implications beyond their functionality. Definitely, as Giorgio Muratore also warned, the challenge was to give a new form to the new defense woks, "form" that at the same time contains the maximum of technological response and the maximum of symbolic and visual significance.

This process, which finalized as we can know from our current perspective with the adoption of the bastioned systems as the defensive form par excellence, far from being a continuous and linear walkthrough, was characterized by numerous particular contributions that over the years defined certain tendencies that ended up defining this bastioned system itself. In my opinion, the main success of these attempts was to use geometry itself for formalize the fortifications and bring together in these new defensive systems their double character of functional limit and symbolic boundaries, inherent as we have seen to this idea of urban limit and of which - according also to Giorgio Muratore - the city itself could not be dispensed with.

The first effort against the power of artillery was to oppose passive resistance. The top of the elevated medieval towers and walls were cut, walls were thicken and new defensive elements were developed: rounded cubes, curved planes and curved surfaces for example. As Francesco Paolo Fiore stated, the resistance by the solidity of the materials budget up to the resistance through the form. The first notable attempts to give formal and visual coherence to this defensive system must be attributed to Francesco di Giorgio Martini in his fortifications for the Duchy of Urbino. In a structure still clearly dependent on medieval schemes, these martinian defensive buildings are characterized by a sequence of broken and sloped planes alternated with rounded and polygonal towers with a great plastic and formal coherence.

Grosso modo, after these first passive efforts, followed a progressive assimilation of artilleries power as a useful weapon also for the defense. The straight line drawn up by the shot of the cannon, instead of being faced by the curves and slopes on first fortifications, started to take importance as modelling elements for the defenses. Fortifications began to use flanking systems to protect the walls laterally, the cubes were transformed into polygonal bastions with large terraces to settle artillery and the general geometry of the walls began to adapt to these shooting angles. In this sense, the work of the leading Renaissance architects was significant to prevent the definition of these new defensive elements from being based solely on technical and military judgements. The hand-drawn sketches of Leonardo da Vinci in its codices or Michelangelo's own drawings for the Florentine walls speaks for themselves regarding to the searching for a formal expressivity in their fortification projects. [figures 3 and 4]

The crucial step towards defining the new image of the urban façade occurred when the communion between these two answers - the passive and the active one - make easier the establishment of a coherent formal system where all the parts were linked with each other through clear geometrical connections. In Henri Focillon's words, nothing is more seductive than to show the form submitted to an internal logic that organizes it, where the variation of the form itself does not depend on the use of strange contributions, on the use of a

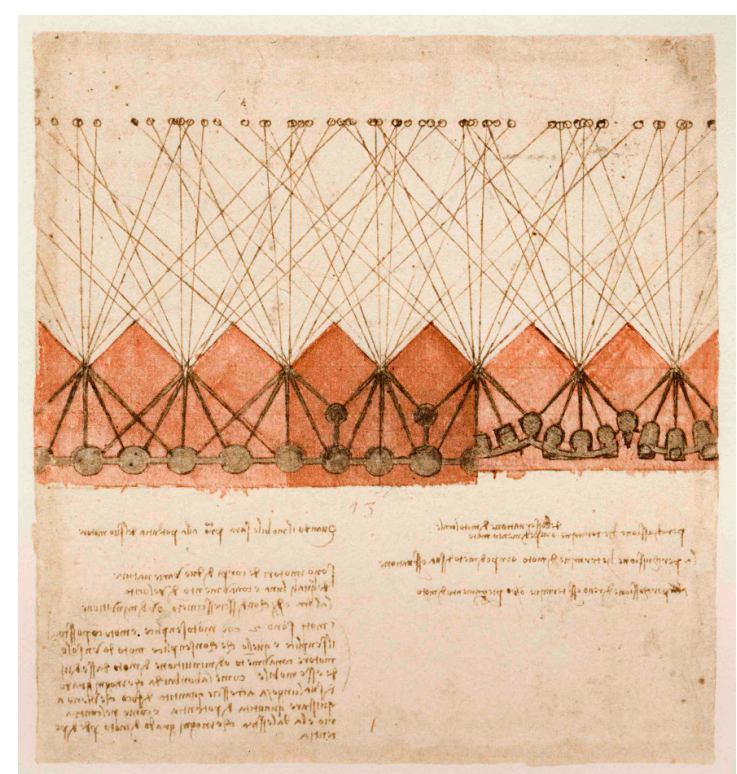

Figure 3. Leonardo da Vinci's drawing, Codex Atlanticus 0767r 


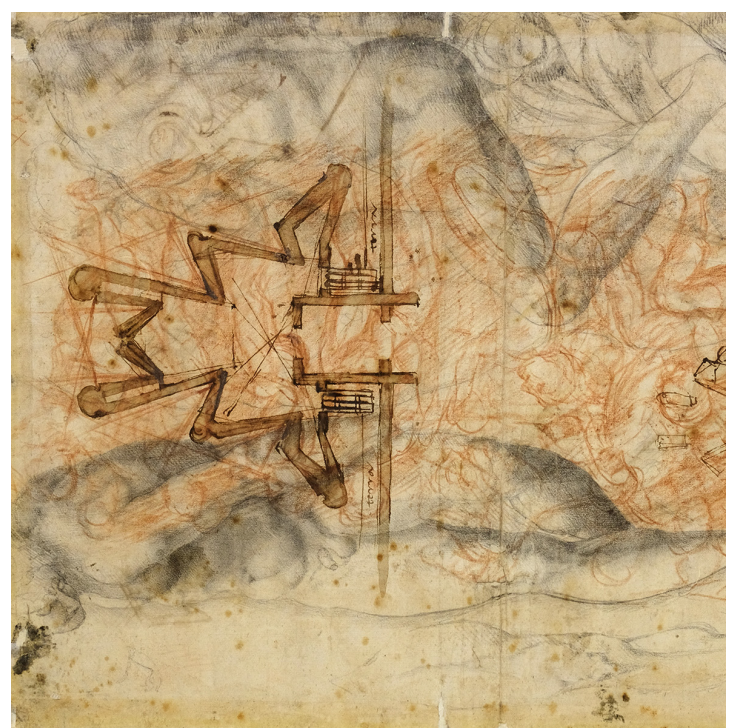

Figure 4.One of Michelangelo's sketches for the fortifications of Florence, Casa Buonarroti 27Av

random choice - as it happened until then - but on the game managed by its own rules. And it were precisely these simple geometrical rules, summarized and concretized in their definitive form by Antonio da Sangallo the younger for the third decade of 16th century, which allowed, as Francesco Paolo Fiore also affirms, to synthesize architectural stability - that is, formal and symbolic coherence - with few and simple offensive-defensive rules.

This rules contributed to reach a new defensive system that could be easily adapted to any location; a system that gave a unitary support in which project the symbolic and representative aspects of the city, and that also improves the formal unity of the whole, reinforcing in this way, the image of these new urban boundaries. Proof of this success are not only the several defenses made in many cities according to this geometrical system, but also its use since then - practically without any exception -in al Renaissance Ideal Cities treatises, where the deep geometrical order of these bastioned walls clarity reinforced the geometrical idea of Renaissance city. As an application of these Ideal Cities, it is not only the well-known city of Palmanova, but also all those citadels built in representation of the governing power - Florence, Pamplona, Antwerp, Turin, etc... - not by chance, built in form of miniature cities which follows the simpler geometric scheme originated in this defensive system: the fortified pentagon.

In conclusion, the efforts made by these Renaissance architect generations succeeded in preserving the nature that characterized the walls from ancient times as vera facciata of the city. The new fortification system developed during so many decades, undoubtedly was able to replace the medieval ones, and also contributes to the emergence of a new idea of city which, without essential variations, become the image of our European cities and all those new cities that were founded on colonial lands throughout the world - well into the 19 th century.

\section{Lessons for the contemporary city: two examples of recovering of this historic city boundary}

The demolition of fortifications that surrounded the historic city, its massive growth and the transformation of the skyline of our cities among many other reasons - has unbalanced this center-limit relationship that has been until today an essential part of its urban structure. From this Italian experience can be valued the relevance that for the city had not only the definition of its interior structure, but also its representation outwards. That is, from this experience can be learned the relevance of configuring a boundary that delimits an inner enclosure - the city itself - and an outer space - its territory - delimited by an effective façade that gives to the city its own unity and image. Althoug this inside-outside relationship has changed in the las century, opposed to what happened between the 15th and 16th centuries, there are few cases in which the redefinition of this historic cities boundaries has been consciously reconsidered. Exceptis excipiendis, the case of the famous Viennesse Ringstrasse for example, cities have favored a continuous expansion where, at best, in this transition between the old walled city and its successive extensions is placed only an empty space or an uncertain street, in short, a blurred memory of this forgotten limit. 
Despite the fact that the development of the contemporary city seems to continue on other paths - unrelated to its definition as a unitary structure - regarding to the historical city it still seems possible - even essential from my perspective - to recover and reinforce the memory of this missing urban façade. Only this way, through the reaffirmation of the singularity of the historic cities, can be recovered the relation between these essentially different two cities which are destined to coexist: the historic city and its respective extensions.

Among the projects that have recently tried to resolve this question, I have decided to outline two interventions where the influence of the lessons learned from this Renaissance experience - the use of a formal system based on the geometrical clarity as a substitute of medieval fortifications - is manifest. These are two projects made in two cities, diverse for one another, Milan and Hondarribia, but with a common feature: the use of formal recoveries of their fortifications - the first one through formal evocation, the second one by restoration - as a way to give back to these cities the memory of their historic urban image and to redefine their relation with their suburbs. In the project proposed by Giorgio Grassi for Milan [figure 5] the restoration of this urban

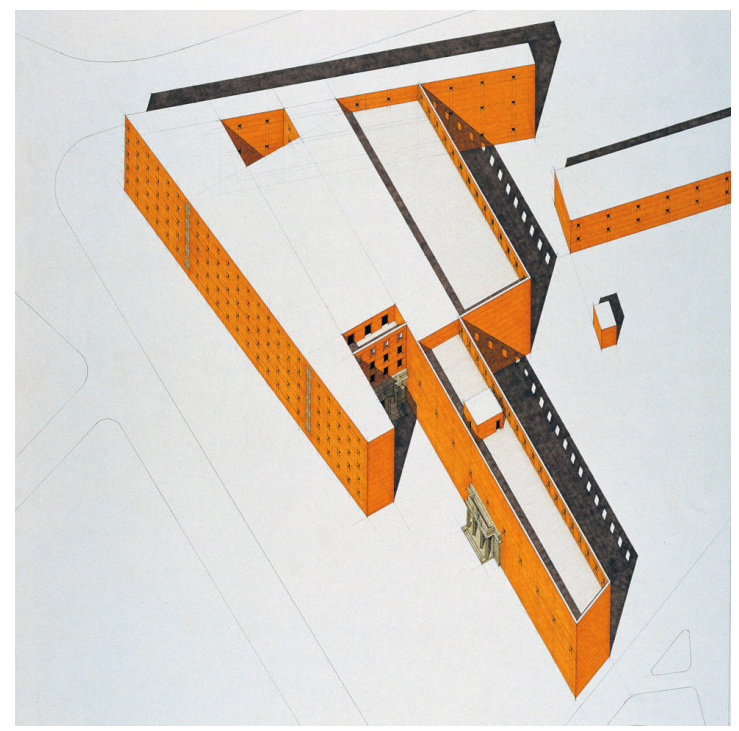

Figure 5. Axonometric view of Giorgio Grassi's proposal for Porta Volta at Milan. image is based on the construction of new buildings on the footprint of the disappeared Porta Volta bastion, positioned in the angle where the old fortifications built by Spaniards gave a sharp angle to connect with the Castello Sforzesco's walls. As Grassi confirms, the demolition of the walls made this boundary unrecognizable and transfigured drastically the image of the historic city. This image, is recovered in this grassian project erecting a new public buildings: a library following the bastioned volume of the razed fortifications and some car park buildings recovering the respective curtains of walls. The geometrical and volumetric clarity of the intervention, as well as respecting the order of the old walls, continues the same spirit that - as we have seen in this text - marks the essence and raison d'être of the fortifications developed in the Renaissance from times of Francesco di Giorgio Martini, evoking in a masterful way the character of this urban limit that Grassi wished to reconstruct in his project. This recovering process of the urban façade is rounded here with the placement by anastylosis of the two old city-portals of Porta Volta - currently dismantled and preserved by pieces - on the façades of the new buildings.

In the project for Hondarribia, began by Manuel Manzano Monis in the sixties and continued by Alberto Ustarroz and Manuel Iñiguez, the recovering process of the walled image of the city is realized through its reconstruction and restoration. Partially demolished by French army and forgotten for over a century by citizens, these fortifications remained in state of ruin. The city was extended beyond its walls, and it was not until the second half of 20th century when Manuel Manzano began the rehabilitation of some parts of the historic city and promotes an intervention that was vital to recover the image of this urban façade: the reconstruction of Queen's Bastion in the southwest corner of the walled city, in a very similar context to the proposal of Giorgio Grassi for Milan. The reconstruction of this walled corner succeeded becoming the main reference of the urban fortified boundary and meant a turning point with respect to the attitude of the city about its historical center. It also opened the way for the restorations were 

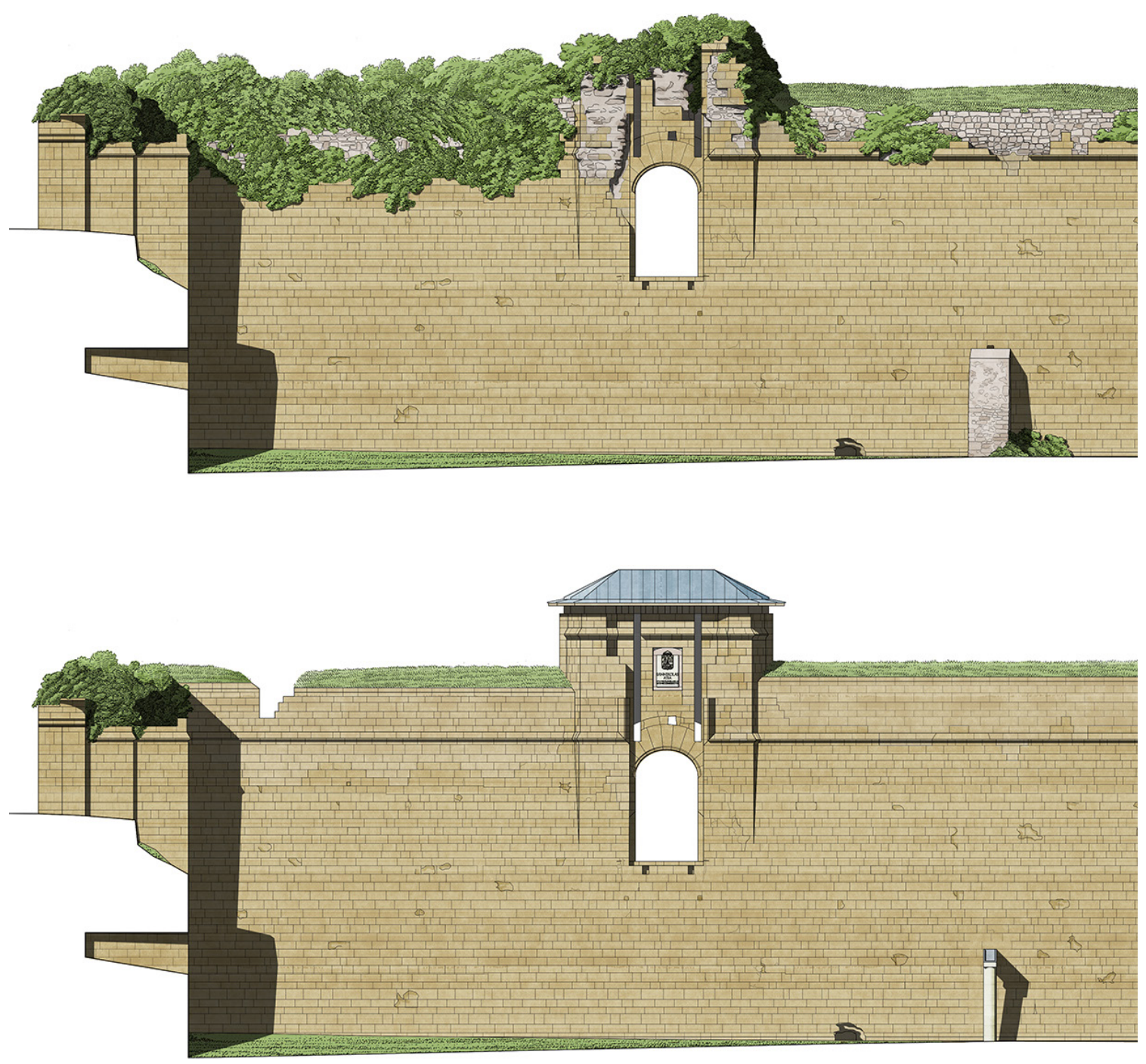

Figure 5. Elevation of the project made by Iñiguez\&Ustarroz for the reconstruction of Hondarribia's walls

recently made in the rest of the fortifications by Alberto Ustarroz and Manuel Iñiguez. These architects completed the restoration of the Queen's Bastion and recovered the image of the walled curtains, as can be seen in the image that accompanies the article. [figure 6] This intervention gives back to the city the memory of its lost walled front, recovering the geometric presence of its fortifications and emphasizing the two main access doors to the historic center.

Two different examples, both in context and in their materialization, but which coincides on the same objective: the restoration of the city's walled enclosure as a way to reclaim the significance of the historic city and to restore its relationship with the contemporary one.

\section{References}

Bruschi, Arnaldo. Oltre il Rinascimento, Architettura, città, territorio nel secondo Cinquecento. Milano: Jaca Book, 2000. 260 p.

Faucherre, Martens, Paucot. La genèse du système bastionné en Europe. The genesis of the bastioned system in Europe. 1500- 
1550. Orthez: Université d'Aix-Marseille, 2014. 239p.

Fiore, Muratore, Valeriani. I castelli: Architettura e difesa del territorio tra Medioeve e Rinascimento. Novara: Istituto Geográfico de Agostini, 1978. 527p.

Hale, J.R. Renaissance War Studies. London: The Hambledo Press, 1983. 524p.

Marani, Pietro C. Disegni di fortificazioni da Leonardo a Michelangelo. Firenze, Cantini, 1984. 126p.

Ossana, Seta. Imago Urbis: the memory of place in cartography from the Renaissance to Romanticism. Lugano: Silvana Editoriale, 2016. 255p.

Rossi, Aldo. L'architettura della città. Turin: CittoStudi Edizioni, 1978. 137p.

Sica, Paolo. L'immagine della città. Da Sparta a Las Vegas. Roma: Biblioteca universale Laterza, 1970. 358p.

Vasari, Giorgio. Le vite de' più eccellenti pittori scultori e architettori. (text of the Giuntinan Edition, 1568) Italia: Istituto Geografico de Agostini, 1967. 9 vol.

Díez Oronoz, Aritz. 2015. Los proyectos de reforma de las fortificaciones de Hondarribia durante la época borbónica: 1719-1794. Escuela Técnica Superior de Arquitectura de la Universidad del País Vasco, Donostia-San Sebastián.

Fernández Antuña, César M. Murallas de Hondarribia, de la cerca medieval al recinto abaluartado. Hondarribia: Hondarribiko Udala, 2002. 367p.

Izaguirre Iguiñiz, Martin. Cartografía antigua y paisajes del Bidasoa. Irun: M. Izaguirre, 1994. 350p.

Arquitectonica Art\&Architecture. Iñiguez, Ustarroz. $\mathrm{n}^{\circ}$ Especial, julio 1991. Bilbao: Instituto de Arte y Humanidades. pp. 9-110

Crespi, Dego. Giorgio Grassi. Opere e progetti. Milano: Mondadori Electa, 2004. 455p.

Grassi, Giorgio. Arquitectura lengua muerta y otros escritos. Barcelona: Editorial del Serval, 2003. 221p.

Grassi, Lahuerta. Progetti per la città antica. 24 Ore Cultura, 1995. 96p. 